\title{
岩石形成プロセス抽出のための可視化情報計測*
}

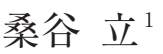

\section{Rock-forming-process Extraction through the Integration of Visualization, Informatics and Measurement}

Tatsu Kuwatani

\section{1. はじめに}

岩石は，固体地球のダイナミクス，たとえば，造山運 動, 地震・火山の発生メカニズム, 資源の形成メカニズ ムなどを実証的・物質科学的に解明する唯一の貴重な手 がかりである，岩石学の本質は，採取した岩石という 「結果」から, 岩石形成に関する物理化学的過程（プロ セス）に相当する「原因」を推定する逆問題といえる. しかしながら, 得られる情報は常に断片的不完全であり, この逆問題を解くことは容易ではない。よって, 計測・ 分析対象から有効に定量的デー夕を抽出し, かつ, 取得 データからプロセスに関する本質的な情報を最大限に引 き出す必要がある ${ }^{1)}$.

近年, 自然科学の計測・観測データを高度な数理・情 報科学技術で解析することで, デー夕の背後に潜む本質 的情報を抽出する試みがなされており，デー夕駆動型ア プローチもしくは情報・計測融合アプローチなどと呼ば れている，著者のグループは，2010 年ごろからこのよ うなアプローチを導入し, 数理・情報科学者と連携する ことで, 地球物理学や地質学, 環境科学などを含む幅広 い地球科学分野の様々な問題に取り組んできた ${ }^{22}$.

本稿では, 著者らの行った情報・計測融合型アプロー チによる岩石学的研究について, それぞれの研究におけ る可視化の役割とともに簡単に紹介する。次節では, 岩 石組織からのプロセス抽出について, 化学組成空間分布 の定量可視化と, 岩石の経験した温度圧力履歴推定の話 題を取り上げる. 続く 3 節においては, 多数の地球物質 試料の高次元化学組成データを次元圧縮により可視化し, 地球科学プロセスを抽出押よび定量化する研究の枠組み について, 岩石の風化（物質移動）プロセスの抽出を例 に紹介する。最後に, 岩石プロセス抽出に関して, 情 報・計測融合および可視化の側面から今後の研究の方向 性などについて議論する.

原稿受付 2020 年 7 月 20 日

国立研究開発法人海洋研究開発機構 海域地震火山部門

（） 237-0061 神奈川県横須賀市夏島町 2-15，

E-mail : kuwatani@jamstec.go.jp)

\section{2. 岩石組織からのプロセス抽出}

岩石形成のプロセスを知るための最も基礎的な方法は, 単一の岩石試料に注目した $1 \mathrm{~mm}$ から数 $\mathrm{cm}$ スケール の範囲における，光学掞よび電子顕微鏡を利用した岩石 組織の観察・記載である，岩石中に含まれる複数種類の 鉱物の同定や微細構造の記載から, 岩石の形成温度圧力 条件やその際に進行した化学反応や変形過程などを推定 することが可能である。これらの記載を正確かつ詳細に 行い, プロセスの詳細を定量的に推定するためには, 各 構成鉱物の化学組成の測定も必須となる。これを可能に する岩石学の基礎分析装置が電子プローブマイクロアナ ライザ（Electron Probe MicroAnalyzer: EPMA）であ る. 本節では, EPMA を用いた岩石組織の定量可視化 およびプロセス推定の試みを紹介する。

\subsection{X 線元素マップの定量可視化}

EPMA とは, 対象物への電子線の照射により発生す る特性 X 線の波長と強度から, 構成元素を分析する走 查型電子顕微鏡装置である. EPMA の多様な機能の中 で, 点分析は, 数 $\mu \mathrm{m}$ 径の電子線を一点に一分間以上に わたり照射することで，局所的な元素組成を定量測定す る。一方，面分析では，電子線を広範囲・高速（たとえ ば，一点あたり数十から数百ミリ秒) に走査することで, 各元素の相対的な多寊の空間分布を可視化する (Fig. $1)$.

面分析により, 岩石組織と元素の組成分布の関係性が 可視化され, より詳細な岩石組織プロセスの推定が可能 となった。その一方で，面分析で得られるデー夕はあく まで相対值であり, 定量的な数理解析は難しい. そのた め, 大量の画像データが得られても, 岩石形成プロセス について，それを見る研究者の直感的理解と定性的な解 釈に留まっているのが実際であった。

そこで, 著者らのグループでは, EPMA 分析から定 量的な組成画像デー夕を高精度・高速に得る方法を開発 した ${ }^{3)}$. 具体的には, EPMA で取得できる定性面分析 デー夕と定量点分析デー夕を統計的に統合することで, 定量的鉱物組成画像デー夕を作成する系統的手法を開発 した．最近，世界的にも同様の研究が盛んになっている 


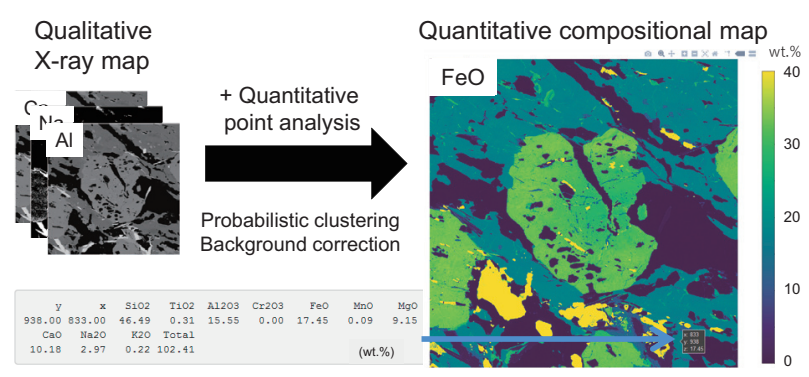

Fig.1 Quantitative compositional imaging of rock texture.

が4)，提案手法では 1 ピクセル内の鉱物種の存在比を決 定するソフトクラスタ分析と特性 X 線強度の理論式を 活用することにより，従来手法と比較して高精度・高速 測定を可能にした（Fig.1）。これまでの岩石学研究で は, 数〜数十点ほどの化学組成定量スポットデータのみ が定量解析に用いられることがほとんどであった。本研 究により, 数十万点ほどの膨大な 2 次元組成データが数 理解析に資する定量データとして得られることになる.

これは, 今後の岩石組織解析の方法論を変えうるポテン シャルを持つものといえよう.

\section{2 温度圧力履歴の推定}

ここでは，鉱物の化学組成からプロセスを抽出する研 究例について簡単に紹介する。岩石中には, しばしば, 鉱物粒子の中心から縁辺にかけて，化学組成が同心円状 に変化する組成累帯構造と呼ばれる特徵的な組織がみら れる.これは, 鉱物粒子成長時の物理化学的外場の状態 変化の様子を反映したものであることが多く, 理想的な 条件が揃った場合, 熱力学相平衡論を用いて化学組成 データから温度㧍よび圧力の履歴（P-T path）を推定 することが可能である ${ }^{5}$. 温度圧力履歴の正確な推定は, 地下深部の熱史や造山運動のダイナミクスの直接的な理 解につながり, 変成岩岩石学において最も重要な課題と されている。

著者らのグループでは, 組成累带構造を持つ鉱物粒子 から, ベイズ推論を基礎とする数理的枠組みにより, 温 度圧力履歴を高精度に推定する方法論の開発を続けてい る. 最近では, ベイズ推論的画像解析手法であるマルコ フ確率場（Markov Random Field: MRF）モデルにより, 鉱物包有物を用いた汎用性の高い温度圧力履歴推定法を 開発した6)。また，鉱物粒子成長の時間発展則を仮定す ることで, 組成累带構造から温度圧力履歴の時間的推移 を推定する手法を新たに開発した ${ }^{7)}$ (Fig. 2)。この手法 では，通常は時系列デー夕を対象とするデー夕同化技術 を拡張・一般化することで, 空間データのみから過去の 時間的な情報を抽出している. 現時点では，1 次元の化 学組成データしか扱えないが, 今後, モデルを発展させ ることで, 前小節で述べたような 2 次元組成データの解 析も可能になる。これにより, 詳細かつ信頼性の高い温 度圧力履歴の推定や，これまで無視していた粒内元素拡 散の効果を考虑したモデリングなど，様々な応用が期待
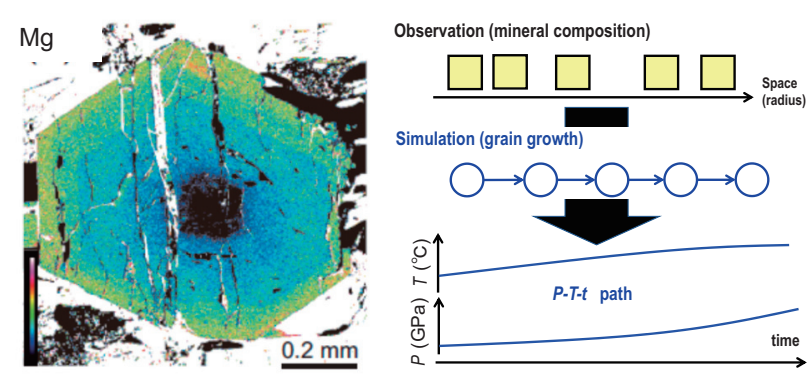

Fig. $2 \quad P-T$ path estimation from compositional zoning.

できる.

\section{3. 全岩組成データからのプロセス抽出}

前節までは, 単一の岩石試料に注目し, その微細組織 の可視化を通じてプロセスを推定する場合を考えてきた. 一方, 本節では複数の岩石試料に関する計測デー夕を集 団的性質として可視化し, 全体䇽よび個々の岩石に働い たプロセスを推定する試みを紹介する。

\section{1 高次元元素組成データの次元圧縮による可視化}

注目する岩石を特徴づけるための最も重要なデー夕が 全岩化学組成であり, 玄武岩・安山岩・カコウ岩など, 岩石の分類基準としても利用されている，全岩化学組成 とは, 岩石を数 $\mathrm{cm}$ 程度の大きさ，もしくはそれ以上の 大きさで平均化した多元素の含有量のことであり, 重量 パーセント濃度（wt.\%）や $\mathrm{mg} / \mathrm{kg}$ （あるいは ppm）な どの単位で表現される，岩石を粉末状もしくはビード状 に成形したものを蛍光 X 線分析（XRF）などの計測に より取得できるデータである。

こうして得られた全岩化学組成データは 2 次元のグラ フ上に可視化される。研究者は, その分布の様子を試料 の産地や属性と照らし合わせながら, 地球科学の専門知 を総動員させることでプロセスを推定していく8). 最も 古典的な可視化方法である Harker diagram は, 主要元 素（主に地球全体で酸化物としておよそ $1 \mathrm{wt}$ \%\%以上含 まれるとされる $\mathrm{Si}, \mathrm{Ti}, \mathrm{Al}, \mathrm{Fe}, \mathrm{Mg}, \mathrm{Ca}, \mathrm{Na}, \mathrm{K}$ などの総称) について, 縦軸に各元素, 横軸に $\mathrm{SiO}_{2}$ をとったもので ある。また，岩石の種類や注目したいプロセスにあわせ て，プロセスを反映していると考えられる重要な元素を 経験的に選択し，2 次元図上で分布を可視化することも 多い。例として, 茨城県の表層土壤試料 $\left.{ }^{9}\right)$ を $\mathrm{Al}-(\mathrm{Ca}+$ $\mathrm{Na})-\mathrm{K}$ の三角プロットに示した (Fig. 3)。このグラフ

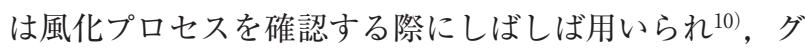
ラフの上部に近づくほど，風化の影響を強く受けている ことを示している.

上述のような古典的な全岩化学組成の可視化方法に対 して，著者らのグループでは，多元素のデー夕を活かす データ駆動型の可視化およびプロセス抽出を提唱してい る11)。これは, 以下で示されるような, 全岩化学組成 データセット $\boldsymbol{Y}$ の行列分解により実現される.

$$
\boldsymbol{Y}=\boldsymbol{A} \boldsymbol{X}
$$


(a)
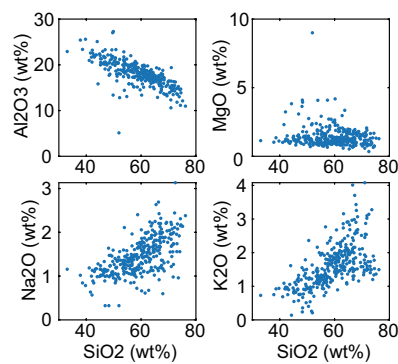

(b)

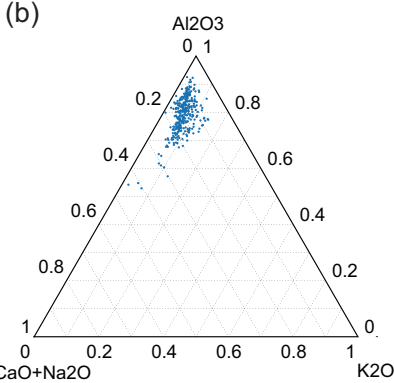

Fig. 3 Chemical composition of surface soils in Ibaraki Prefecture ${ }^{9)}$ plotted on Harker diagrams.

ここで, 行列 $\boldsymbol{A}$ は基底ベクトルを並べたもの, 行列 $\boldsymbol{X}$ はそれぞれのサンプルに対する基底べクトルの強度から 構成されるスコアベクトルを並べたものである。また， 行列 $\boldsymbol{Y}$ はなんらかの前処理を施したものとする，行列 分解の方法は無数に存在するが，代表的なものは，主成 分分析や因子分析・独立成分分析などとも対応し，多変 量解析として頻繁に利用されている，得られた各基底べ クトルを, 化学組成を変動させる要因となる個々のプロ セスとみなすことで，岩石形成のプロセス抽出に利用で きる。この方法は, 従来手法とは異なり, 多元素の情報 を活用できる点，および，プロセスを分離できる点が大 きな利点といえるだろう。

Fig. 4 は，分散共分散行列の固有值分解に対応する主 成分分析を用いて, 先述の表層土壤の化学組成データ9) の可視化を行った結果である。（a）は固有（主成分）べ クトルを示しており，それぞれのべクトル形状は対応す るプロセスに由来する組成変動に関する元素の相関関係 を反映している，この場合は，元素の移動性や鉱物組成 に関する地球化学的先験的知識から, PC1 および PC2 はそれぞれ，元素溶脱に伴う化学風化，および，原岩組 成バリエーションを示しているものだと推定される。ま た，(b) は PC1,PC2 のスコアを 2 次元散布図で示した ものであり，個々のサンプルが被った各プロセスの強度 を評価できる。

実際は，プロセスの非線形性や組成データの定数和制 約に由来する問題などがあり，正確にプロセスを抽出で きているかどうかの評価には，慎重な検討が必要である. また，対象とするプロセスやデータセットに応じて，適
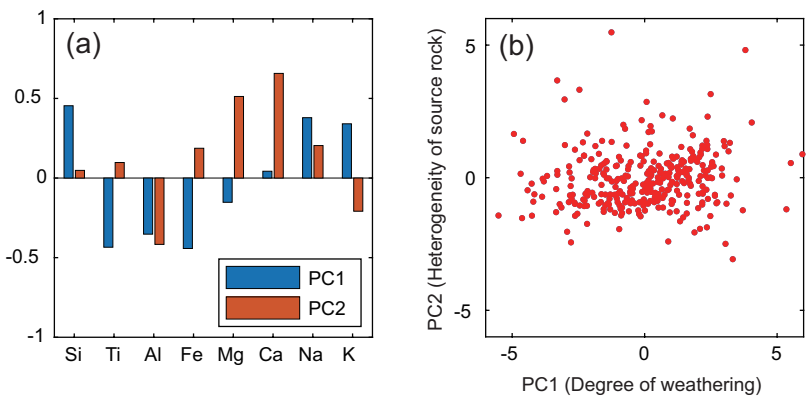

Fig. 4 Results of PCA for the dataset shown in Fig. 3. (a) Eigen vectors (b) Score plots for PC1 and PC2.
切な行列分解や前処理方法を選択しなければならない. 研究の一例として, 著者らのグループでは, 組成デー夕 の定数和条件を考慮した非負值行列分解を用いることで, 四国中央部に露出する変成岩の全岩組成データから，海 洋プレートの沈み込みに伴う化学反応プロセスの抽出に 成功している12).

\section{2 参照保存量の自動決定とプロセス定量化}

全岩化学組成のバリエーションを生み出す原因となっ た岩石形成プロセスを扔打よそ特定できたとしても，プ ロセスの詳細を定量化することは実は容易ではない。こ こでは，プロセスを被っている岩石試料と被っていない 岩石試料の化学組成データセットから，プロセスにより 岩石中の元素が移動した際の増減量を定量的に推定する 問題を考えたい。

一見すると，この問題は，両者の差分をとればよいだ けの簡単な問題のように考えられるが，化学組成デー夕 が絶対量ではなく相対量であるために, 両者は単純に比 較できず，組成デー夕の情報のみでは原理的に推定不可 能な難問とされている。従来は, 研究者が地球化学的知 識を基に経験と勒により, 試料相互の比較基準となる参 照保存量 (reference frame: プロセス前後に絶対量とし て不変となる量）を仮定する（たとえば，体積や全質量， もしくは特定の元素の含有量を一定とみなす）ことで, 元素の增減量を推定してきた ${ }^{13,14}$.

最近，著者らは，複数試料の化学組成データから，適 切に参照保存量を自動決定し，物質移動量を定量的に推 定する方法を新たに提案した ${ }^{15)}$. 提案手法は，スパース モデリング（自然界に内在するスパース性に基づいて， 高次元データセットから少数の重要な次元を抽出する数 理的枠組み）の考え方を活用することで，個別元素の動 きにくさをデータから自動的に学習する。これにより， 参照保存量が自明でないようなプロセスやデータセット についても，客観的・定量的に物質移動量を推定可能て ある。本手法と，前小節で示した行列分解手法を組み合 わせることで，全岩化学組成データセットから系統的・ 定量的に複数の岩石形成プロセスを分離・抽出する枠組 みが構築できるものと期待されている.

\section{4. おわりに}

以上，岩石形成プロセスの抽出について，単一試料の 岩石組織に注目する場合と複数試料の全岩組成デー夕の 集団的性質に注目する場合の二つの典型的な問題設定に おける研究例を簡単に紹介した。両方のケースにおいて, 計測デー夕を情報処理により適切に可視化し，解析者の 専門知を駆使してプロセスを解釈する必要があった。ま た，定性的なプロセス解釈に留まらず，定量的なプロセ ス抽出を実現するためには、ベイズ推論を用いた時空間 のモデリングや，スパースモデリングなどを用いた高次 元デー夕解析により，系統的なプロセスモデリングをす る必要があることもみてきた。つまり，岩石からのプロ 
セス抽出のためには，計測デー夕の取得から始まり，計 測デー夕の適切な可視化, 専門知を駆使した岩石形成プ ロセスの解釈，それに伴う定量的なモデリングという一 連の研究過程が存在する.

本稿の冒頭において, 岩石学の数理的本質は非常に難 解な逆問題であることを強調した。このような非適切な 逆問題では, 入手可能な計測デー夕のみでは, 唯一解を 導き出すことは難しく, 解析者の専門知や経験, 勒に よって, 様々な仮定を加える必要がでてきてしまう。前 段落で示したほとんどの研究過程において解析者の主体 的な判断は不可欠であり, むしろ, 必要な場面に扔いて は, 熟練の専門知と経験・直観を積極的に活かしていく ことも重要であろう。つまり, 計測・可視化・情報処理 の過程の中で専門知を加えつつ絶えずフィードバックを 与えながら，プロセスの本質に漸近的にアプローチして いくという，いわゆる Human-in-the-Loop の解析が重 要となる ${ }^{16)}$ 。これを実現するためにも，プロセス発見を 促す Human-in-the-Loop な可視化や, 組成デー夕性・ サンプリングバイアスなどを持つ地球科学データの特性 を考慮した可視化など, 岩石学のプロセス抽出に最適な 情報処理㧍よび可視化方法の開発が望まれている. 今後, ますます, 対象を解析する地球科学者と, 可視化や機械 学習などの先端的方法論を開発する数理・情報科学者の 密接な連携が必須となっていくだろう。

\section{謝 辞}

本研究は, 科学技術振興機構戦略的創造研究推進事業 CREST/さきがけ複合領域「情報計測」の第一期さきが け研究課題「岩石からのプロセス抽出: 究極の逆問題に 挑むべイズ計測」（2016-2019 年度 JPMJPR1676）の支 援を受けました，本稿で示した共同研究は，新学術領域 「疎性モデリング」などで知遇を得た多数の数理・情報 科学者との連携によるものです，特に，可視化に関する 考察は, 藤代一成教授, 高橋成雄教授らとの議論が参考 になりました。また，以下の助成も受けました：JST CREST (JPMJCR1761), JSPS KAKENHI (JP19K04027, 18H03820), ERI, U.Tokyo (ERI JURP 2018-B-01) . ここ に記して，深謝申し上げます。

\section{参考文献}

1 ) 岡本敦, 桑谷立, 変成岩組織と鉱物組成累帯構造からの情報 抽出：フォーワードモデルと逆解析, 地質学雑誌 123 (2017) 733-745.

2 ) 桑谷立, 地球科学プロセス解明のためのデータ駆動型解析一 地質学分野に扮ける応用例一, 情報地質 29 (2018) 49-60.

3 ) A. Yasumoto, K. Yoshida, T. Kuwatani, D. Nakamura, M. Svojtka, T. Hirajima, A rapid and precise quantitative electron probe chemical mapping technique and its application to an ultrahigh-pressure eclogite from the Moldanubian Zone of the Bohemian Massif (Nove Dvory, Czech Republic), American Mineralogist 103 (2018) 1690-1698.

4) P. Lanari, O. Vidal, V. De Andrade, B. Dubacq, E. Lewin, E.G. Grosch, S. Schwartz, XMapTools: A MATLAB(C)-based program for electron microprobe X-ray image processing and geothermobarometry. Comp. Geosci. 62 (2014) 227-240.

$5)$ F. S. Spear, Metamorphic phase equilibria and PressureTemperature-Time paths. Monograph 1, Mineralogical Society of America, Washington, D.C. (1993).

6 ) T. Kuwatani, K. Nagata, K. Yoshida, M. Okada, M. Toriumi, Bayesian probabilistic reconstruction of metamorphic P-T paths using inclusion geothermobarometry, J. Mineral. Petrol. Sci. 113 (2018) 82-95.

7 ) T. Kuwatani, H. Nagao, S. Ito, A. Okamoto, K. Yoshida, T. Okudaira, Recovering the past history of natural recording media by Bayesian inversion, Phys. Rev. E 98 (2018) 043311.

$8)$ H. R. Rollinson, Using geochemical data: evaluation, presentation, interpretation. (Longman Geochemistry Series), Routledge, London (1993).

9 ）中村謙吾, 桑谷立, 駒井武, 山崎慎一, 主成分分析を用いた 表層土壤の元素濃度の地球化学的特徵の抽出, J. MMIJ 134 (2018) 13-21.

10) H.W. Nesbitt, G. M. Young, Prediction of some weathering trends of plutonic and volcanic rocks based on thermodynamic and kinetic considerations, Geochim. Cosmochim. Act. 48 (1984) 1523-1534.

11）桑谷立, 中村謙吾, 渡邊隆広, 小川泰正, 駒井武, 主成分分 析を用いた次元圧縮に基づく東北地方太平洋沖地震による津 波堆積物の地球化学的特性評価, 地学雑誌 123 (2014) 923-935.

12) K. Yoshida, T. Kuwatani, T. Hirajima, H. Iwamori, S. Akaho, Progressive evolution of whole-rock composition during metamorphism revealed by multivariate statistical analyses, $J$. Metamorph. Geol. 36 (2018) 41-54.

13) R. L. Gresens, Composition-volume relationships of metasomatism, Chem. Geol. 2 (1967) 47-55.

14) J.A. Grant, The isocon diagram-a simple solution to Gresens' equation for metasomatic alteration, Econ. Geol. 81 (1986) 1976-1982.

15) T. Kuwatani, K. Yoshida, K. Ueki, R. Oyanagi, M. Uno, S. Akaho, Sparse isocon analysis: A data-driven approach for material transfer estimation, Chem. Geol. 532 (2020) 119345.

16）藤代一成, 高橋成雄, 渡辺一帆, H.-Y.Wu, スパースモデリン グと可視化，電子情報通信学会誌D 99 (2016) 466-470. 